\title{
Tumefactive multiple sclerosis presenting with tonic-clonic seizure
}

\author{
Amrou Ali Idris, Tahmina Begum, Kenneth Rowland Verlage, Mashrafi Ahmed
}

Texas Tech University, Amarillo, Texas, USA

\section{Correspondence to}

Dr Mashrafi Ahmed, mashrafi. ahmed@ttuhsc.edu

Accepted 14 April 2016
CrossMark

To cite: Idris AA, Begum $T$, Verlage KR, et al. BMJ Case Rep Published online:

[please include Day Month

Year] doi:10.1136/bcr-2016215266

\section{DESCRIPTION}

A 37-year-old Hispanic man with no medical history presented with sudden onset of two episodes of witnessed seizure. On arrival to the emergency room, he experienced another episode of generalised tonic-clonic seizure witnessed by the physician and nurses. His seizure was accompanied by tongue biting and postictal confusion, but neither bowel nor bladder incontinence. Each episode lasted nearly $15-20 \mathrm{~s}$ and resolved without intervention. The patient did not have a similar event in the past and family history was negative for seizure disorder. He was not on medication at home and denied recreational drug use. On physical examination, he had postictal generalised weakness but no focal neurological deficit. An initial CT scan of the brain indicated low density focus on the left frontal lobe. Subsequent MRI reported a $2.4 \times 2.2 \mathrm{~cm}$ well-circumscribed lesion with contrast enhancement with neither vasogenic oedema nor mass effect (figure 1, yellow arrow). Multiple white matter plaques were also noted (figure 1, green arrow). Lumbar puncture revealed clear cerebrospinal fluid (CSF) with 3 white cell counts and 0 red blood cell. CSF protein was $14 \mathrm{mg} / \mathrm{dL}$ and glucose, $66 \mathrm{mg} / \mathrm{dL}$. CSF myelin basic protein was $16.3 \mathrm{ng} / \mathrm{mL}$ and eight oligoclonal band was observed in the CSF. All other infectious aetiologies were excluded. The patient was started on methylprednisone for 3 days and discharged with interferon $\beta$.

Tumefactive multiple sclerosis (MS) is a clinical variant of MS, presenting as a mass-like lesion and often associated with oedema or ring enhancement. ${ }^{1}$ The demyelinating areas in the brain are usually large $(>2 \mathrm{~cm})$ lesions mimicking a large tumour. There may be mass effect with compression of the lateral ventricle and midline shift. The radiological differential diagnoses of such lesions are brain abscess, primary central nervous system (CNS) tumour-glioma or astrocytoma, metastatic lesion from a distal primary tumour, toxoplasmosis and CNS lymphoma, etc. ${ }^{2}$ The clinical presentation varies from an asymptomatic incidental finding to confusion, seizure, hemiparesis or hemi-neglect syndrome. In a previously described large case series, ${ }^{3}$ the median age at onset was 37 years (range 8-69). The patients presented with different motor, cognitive, sensory and cerebellar symptoms. The lesions on the brain were often multifocal, and frequently had ring enhancement with a heterogeneous or homogeneous appearance on gadolinium-enhanced MRI. Nearly $50 \%$ of the cases had a relapsing-remitting course. There is no variation in the treatment protocol for this particular variant of MS.

\section{Learning points}

- Tumefactive multiple sclerosis is a rare variant of multiple sclerosis that may present with atypical symptoms.

- Imaging study may often be confusing due to the appearance of the lesion, and cerebrospinal fluid analysis helps to establish the diagnosis.

- Treatment of tumefactive multiple sclerosis is similar to that of other forms of multiple sclerosis. 
Twitter Follow Amrou Idris at @AmrAli80845056

Competing interests None declared.

Patient consent Obtained.

Provenance and peer review Not commissioned; externally peer reviewed.
2 Kilic AK, Kurne AT, Oguz KK, et al. Mass lesions in the brain: tumor or multiple sclerosis? Clinical and imaging characteristics and course from a single reference center. Turk Neurosurg 2013;23:728-35.

3 Lucchinetti CF, Gavrilova RH, Metz I, et al. Clinical and radiographic spectrum of pathologically confirmed tumefactive multiple sclerosis. Brain 2008;131(Pt 7):1759-75.

\section{REFERENCES}

1 Nagappa M, Taly AB, Sinha S, et al. Tumefactive demyelination: clinical, imaging and follow-up observations in thirty-nine patients. Acta Neurol Scand 2013;128:39-47.

Copyright 2016 BMJ Publishing Group. All rights reserved. For permission to reuse any of this content visit http://group.bmj.com/group/rights-licensing/permissions.

BMJ Case Report Fellows may re-use this article for personal use and teaching without any further permission.

Become a Fellow of BMJ Case Reports today and you can:

- Submit as many cases as you like

- Enjoy fast sympathetic peer review and rapid publication of accepted articles

- Access all the published articles

- Re-use any of the published material for personal use and teaching without further permission

For information on Institutional Fellowships contact consortiasales@bmjgroup.com

Visit casereports.bmj.com for more articles like this and to become a Fellow 